\title{
Travessia, memória e marginalização em "a arte de andar nas ruas do rio de janeiro", de Rubem Fonseca
}

\author{
Gilda Vilela Brandäo \\ Brasileira do Programa de Pós-graduação exm \\ Lelras e Lingüist
}

\begin{abstract}
Resumo: Na tentativa de escapar à opressão do presente. o solvitur ambulando AugustoEpilànio escava, sob os escombros da cjdade moderna, residuos de um passado-menória inscrito nos nomes das ruas e nas fachadas dos prédios. Explicitar esse esłorço, suas imagens e combináçōes, é o propósito deste artigo.
\end{abstract}

Palawas-chave: ruat cidade: centro; passado: memória
Résumé : Dans la tentalive d'échapper à l'opression du present. le solvitur ambulando Augusto-Epifanio creuse. sous les décombres de la ville moderne. des résidus d'un passè-mèmoire qui ne cesse pas de s'écrire el de s'inscrire sur les cartes des rues et sur les laçades des bátiments. Expliciter cet eftort. son pouwir associatif d'images e combinaisons. c'est le propos de cel article.

Mors-clés: rue; ville ; centre ; passè; memoire 



\section{À procura de um centro}

Pelo esplendor do passado, portanto, e pela sua má fortuna da atualidade, o convento de $\mathrm{S}$. Antonio da cidade do Rio de Janeiro deve chamar nossa atençāo e tornar-se o objeto de estudo desvelado em alguns de nossos passeios. (MACEDO, 1942, p. 124)

Para narrar a história do escritor-andarilho Augusto-Epifânio - que, na tentativa de diminuir o fosso separando letrados e iletrados, "além de andar [...] ensina as prostitutas a ler e a falar de maneira correta"l-, Rubem Fonseca abre seu conto com a seguinte epígrafe:

Em uma palavra, a desmoralização era geral. Clero, nobreza e povo estavam zodos pervertidos. Joaquim Manue] de Macedo, Un passeio pela cidade do Rio de Janeiro (1862)

De imediato, pōe o leitor de sobreaviso: Fonseca deve ser um leitor assíduo de Joaquim Manuel de Macedo ${ }^{2}$ (1820-1883), cuja temática quase sempre ingênua, da qual são exemplos os romances $A$ moreninha (1844) e $O$ moço loiro (1845), atingiu altos niveis de audiência folhetinesca nos meados do século XIX. Porém, antes de enveredar por prováveis caminhos intertextuais, o narrador instrui o leitor a respeito dos lugares retóricos a ser evitados pelo futuro escritor:

Também [Augusto] toma cautela para que o livro năo se torne um pretexto, à maneira de Macedo, para arrolar descrições históricas sobre potentados e instituições, ainda que, tal como o romancista das donzelas, ele às vezes se entregue a divagaçōes prolixas. (p. 19)
' FONSECA, Rubem.

Romance negro e outras hisfórias. São Paulo: Companhia das Lerras, 1992, p. 12.

De agora em diante, todas as ciraçōes deste conto estāo nesta edição e passarão a ser assinaladas apenas pelo número da página em que se encontram.

${ }^{2}$ Segundo Leite, "Joaquirm Manoel de Macedo satirizou de diversas maneiras as incompreensōes linguiisticas dos viajantes [...]. Macedo. como professor do Colégio Pedro ll e autor de livros históricos sobre o cotidiano carioca, foi dos críticos mais autorizados, se bem que nāo escapasse da necessidade de registrar o "progresso" dos costumes, em sua descrição do Recolhimento de $\mathrm{N}$. S. do Parto (1862). Cf. L.EITE. 1984, p. 31-32. 
A referência a essa obra nāo ficcional de Macedo reitera-se no título do conto, por meio da substituiçāo do substantivo passejo, de sugestào puramente idilica, pelo substantivo arte. Contudo, o termo arre guarda um sentido diverso daquele usualmente concebido: a arte de andar nas ruas do Rio de Janeiro não visaria à Beleza tentativa estética totalmente estérìl. Ao contrário, a ideia conceitual da palavra arte aparece, aqui, compativel com a noção de esforço - forma, aliás, de fazer, também, arte -, visto que se trata de achar a beleza em um lugar onde, talvez, ela não seja encontrável, ou seja, na cidade, "lugar onde o capitalismo, o poder e o dinheiro se tornaram grandezas incomensuráveis". (BENJAMIN, 1993, p. 172).

Tem-se de partida um projeto intertextual (abortado) altamente engenhoso, que é o de criar uma versão paralela ao texto de Macedo-impecável, aliás, tanto na elegância do estilo quanto na lógica argumentativa -, pois, de lá para cá, supóc o narrador, muito coisa pode ter mudado - para pior, talvez - em nossa tapeçaria urbana.

Ao pretender cruzar seu trabalho com ode Macedo, Rubem I'onseca tece seu contraponto, utilizando para isso uma conotação duplamente sarcástica, a começar pelo deslocamento do estatuto social do escritor-narrador, não mais representado por uma figura das altas camadas sociais. mas pelo inexpressivo funcionário público. Augusto Eipânio, que, na condição de ex-empregado da companhia de água e esgotos (assim mesmo em mirúsculas) do Rio de Janeiro deve, seguramente, estar apto para a cmpreitada literária à qual se propōe:

Augusto, o andarilho, cujo nome verdadeiro Lipifânio, mora num sobrado em cina de uma chapelaria feminina, na rua Sete de Setembro, no cenro da cidack, o anda nas ruils o dia inteiro $t^{2}$ purte da hovite. Acredita que yo caminhar pens mo/hor, encontra soluçōes pari us problemas: solvitur ambulando, diz para seus botōes. No compo en que trubalhava na companhia de aguas " esgatos ele pensou em abandonar tudo para 
viver de escrever. Mas Joăo, seu amigo que havia publicado um livto de poesia e outro de contos e estava escrevendo um romance de seiscentas páginas, lhe disse que o verdadeiro escritor nào devia viver do que escrevia, era obsceno, nāo se podia servir à arte e a Mammon ao mesmo tempo, portanto era melhor que Epifầnio ganhasse o pão de cada dia na companhia de água e esgotos, e escrevesse à noite. (p. 11; o grifo é meu)

Para o narrador, é importante ir à cata de um local adequado, a partir do qual seria possível à personagem visualizar resquicios, porventura existentes, de um centro, empreendimento a que Augusto se dedica com afinco, embora precise realizar uma série de contorçôes físicas e torçōes visuais para distingui- $10^{3}$.

[...] Augusto, sentado em frente ao seu enorme caderno de folhas pautadas, anota o que vé ao caminhar pela cidade e escreve seu livro a arte de andar nas ruas do Rio de /aneiro.

Ele se mudou para o sobrado da chapelaria para melhor escrever o primeiro capítulo, que compreende, apenas, a arte de andar no centro da cidade. Não sabe qual capitulo será o mais importante, no fim de tudo. O Rio é uma cidado muito grande, guardada por morros, de cima dos quais pode-se abarcá-la, por partes, com o olhar. mas o centro c mais diversificado e obscuro $e$ antigo, o centro nāo tem um morro verdadeiro; como ocorre com o centro das coisas em geral, que ou é plano ou ć raso, o centro da cidade tem apenas uma colina, indevidamente chamada de morro da Saúde, e para ser ver o centro de cima. e assim mesmo mal e parcialmente, é preciso ir ao morro de Santa Teresa, mas esse morro não fica em cima da cidade. fica meio de lado, e dele não dá para se cer a menor idéia de como é " centro, não se vèem as calçadas das ruas. quando
${ }^{3}$ Citaçōes longas sāo necessárias para nossa argunientaçào e para o bom entendinento do enredo. 
+ Em muitas instîncias תarrativas, Rubem Fonseca utjliza o discurso indireto livre, procedimento pelo qual, como é sabido, a fala do narrador incorpora-se à fala da personagem.

s "Rio est devenule la capitale du Brésil en 1763 [...]. En 1767 , clle représentait à peu près ce qu'elle est aujourd'bui le quartier du pott et la vieille ville. Elle était entourée de coteaux ou collines de granits rotedes [...].

La Place du Palais (aujourd'hui place 15 de Novembre) possedait aussi la prison et le couvent des Carmélites. Derrière le palais se trouvait l' Hôtel de Ville et ie Palais de Justice [...]. La rue principale stappelajı rue Direita (aujourd"hui Primeiro de Março) ; les aut res rues faisaient un anglo droil avec ella. ." (MAURO, 1977, p. I93 Truduçào nossa.) muito vê-se certos dias o ar poluido pousado sobre a cidade.

Em suas perambulaçōes. Augusto ainda rảo saju do centro da cidado, nem sairá täo cedo. O resto da cidade, o imenso resto que somente o satanás da Jgreja de Jesus Salvador das Almas conhece inteiramente, scrá percorrido no momento oportuno. (p. 15-16)

Em princípio, a palavra centro - cercada, como está, por um discurso geográfico - não parece guardar ambivalências, podendo até ser lida (do mesmo modo que "colina" e "morros") em seu sentido literal, denotativo, não metaforizado.

Assim, quando na condiçāo de porta-voz da personagem ${ }^{4}$, o narrador afirma que obstáculos físicos (os morros circundando a cidade) impedem a visão do centro estamos no domínio de um mundo físico reconhecivel, que não nega o real. Nesse sentido, é notável como a linguagem precipuamente referencial, do contista, assemelha-se ao discurso estritamente verdadeiro da História:

O Rio tornou-se a capital do Brasil em 1763 [...]. Em 1767, ela representava mais ou menos o que é hoje o bairro do porto e a cidade velha. Era cercada de morros, ou colinas de granito redondos [...]. A praça do Palácio (hoje praça 15 de Novembro) continha também a prisào e o convento das Carmelitas. Atrás do palácio acharase a Prefeitura e o Tribunal de Justiça [...]. A rua principal chamara-se rua Direita (hoje Primeiro de Março); as outras ruas formaram um ângulo direito, (MAURO, 1992, p. 17; grifo nosso) ${ }^{5}$

Na fabulaçāo de Fonseca, parece que a ênfase nos topônimos corresponde à tática de a personagem ver a cidade sem nela se engajar emocionalmente, já que observá-la a parrir de seus contornos físicos é, também, vêla à maneira de um cartógrafo, neutra e objetivamente. 
Porém, quando o narrador acrescenta:

mas, o centro è mais diversificado e obscuro e antigo

saimos da (falsa) crosta documental e saltamos diretamente para o plano da enunciação literária, para o jogo das convençōes próprias de um universo inventado. Isso porque a reflexão deste narrador onisciente ven crivada de notações enunciativas perspicazes. De saida, a conjunção adversativa "mas" sugere que nảo há probabilidades de exito à vista. Como o procedimento estilistico utilizado é o da iteração de uma unidade linguística (a palavra centro aparece oito vezes no ent recho citado, produzindo, como efeito retórico, um humor ferino, tônica do narrador fonsequiano), essa repetição, eivada de novos sentidos, vem cercada por uma adjetivação vaga. Senão vejamos. $O$ adjetivo "diversificado", cujo sentido mais próximo seria "variado", nāo propōe nada que leve o leitor a estabelecer analogias com o já dito; "obscuro", convenhamos, é um adjetivo abstrato, de forte impressăo subjetiva; "antigo", por sua vez, em oposição a "novo", contém um valor temporal sem comprovaçāo textual. Daí por que "diversificado", "obscuro" e "antigo" parecem mais um conglomerado de vivências armazenadas na mente do narrador. Donde se conclui que este centro que nāo é, ou não quer ser mostrado ao leitor, constitui uma metáfora em gestação, articuladora do texto. $O$ que é, sem dúvida. surpreendente, uma vez que, na economia do rexto, essa motivação - a busca do centro - vai se confundir, mais adiante, com o pivô do processo metafórico: a busca da memótia. Assim, aparentemente separados, centro e memória irão formar, ao término de tudo, sem que quase se perceba, um amálgama só.

Então, já que o centro é invisivel e, nas palavras do pastor Raimundo, "o centro é um mistério" (p.15), é possivel supor que Augusto esteja frente a frente com uma cidade geográfica e culturalmente acêntrica. Seria este seu enigmat escrever um livro sobre um centro que 
nāo se desvenda a olho nu; escrever um livro sobre algo incognoscivel? Como a personagem "solvitur ambulando" ("andando é que se resolve a dificuldade") nào confia no que seus olhos veem, e como os mais puros enigmas só se resolvem, parece, com muito esforço, a solução para Augusto é mesmo percorrer as ruas do Rio de Janeiro à procura de um centro que pudesse porventura congregar o significado histórico e cultural da cidade, matéria indispensável à composição de seu livro, pois nāo é possivel viver em uma cidade - supöe o narrador fonsequiano - sem surpreendê-la sob a angularidade dos marginais que a habitam. Esse projeto vital de Augusto percorre a trama do conto. Para levá-lo adiante, o autor utiliza uma linguagem acentuadamente marcada, na apreciaçào feliz de Vera Lúcia Frollain de Figueiredo, por flashes fotográficos, que a estudiosa estende ao conjunto da obra do autor:

[Na ficção do autor], a arte se reencontra com a cidade moderna através de fashes fotograficos. mas nāo há aí nenhum resquicicio de utopia que nos permite ir além do olho nu, mas nem por isso elimina a subjetividade ou permite atingir essa verdade última. (FIGUEIREDO. 2003, p. 35; grifo da autora)

De fato, se, conforme vimos afirmando, o centro da cidade precisa ser construído a cada passo, os Aashes fotográficos não seriam outra coisa senão uma estratégia de que se serve o narrador para levar sua personagem a interrogar-se, sempre e cada vez que um hash novo, uma nova qualidade, uma nova percepção da cidade se lhe apresentem. Longe de ser digressivo, o flash constitui-se como método. Método de escrita. Método de conhecimento. Enquanto recurso de composiçāo. o fash tem, como elemento de expressão, o corte, que nos leva alternadamente de um cenário para outro. Daí a sucessäo de quadros que re c/am (no sentido fotográfico do termo) a exclusão de seres que nảo sảo marginais por 
opção, como o maneta "[que] vendia um ou dois cigarros para os sujeitos que năo têm dinheiro para comprar um maço inteiro" (p. 28), os grafiteiros semianalfabetos, o catador de papel Benevides Gonçalves, "preto que está sempre embriagado" (p. 32), e o presidente da União dos Mendigos. Essas personagens não têm outro parentesco senão a miséria; sobrevivem de modo tão individualista que não conseguem perceber as semelhanças que as constituem. Radicalizada, essa forma de alienação social nāo permite que cada um veja no outro seu próprio espelhamento. Nesse esboço alienado está Kelly, a prostituta a quem Augusto ensina a ler, e que, ao se pôr a distância desses seres, mostra uma percepção falha de sua condiçăo de marginal: " 'Vamos', diz Augusto segurando Kelly pelo braço. Kelly solta o braço. 'Não me pega não', aqueles mendigos devem estar com sarna; você vai ter que tomar banho antes de se encostar em mim."(p.35).

Ao aderir aos restos da sociedade, o autor de Romance negro e outras histórias estaria dialogando com João do Rio (1881-1921), que, em outro momento histórico, recolheu, por esses mesmos becos e por essas mesmas ruas cariocas, a mesma cotidianidade perversa. Afastando-se do canônico - "[que] sería lo regular, lo establecido, lo admitido como garantía de un sistema mientras que la marginalidad es lo que se aparta voluntariamente o lo que resulta apartado porque, precisamente, no admite o no entiende la exigencia canónica" (JITRIK, 1998, p. 19) -, Joāo do Rio, no conto "D. Joaquina", deu à prostituição feminina, urbana, um tratamento estético. O que já configura uma transgressão a certa tradiçāo romântica de narrar histórias en que tudo é elcvado, espiritual, ideal, festivo e utópico.

Aquele canto perto dos Telégrafos, às nove de um noite de inverno. Em frente, os desrroços da antiga Ucharia, embocando a nua Clapp, cheia de prédios grandes, com lanternas... [...]. Era no centro da cidade. Estava ermo. Parecia ao menos ermo. [...] [As pobres mulheres da praça 
"Já procuramos demonstrat que, na escrita de Joāo do Rio, mantidas as diferenças de gènero, crónica e fiç̧ão interpenetram-se em vários momentos, valorizandonse mutuamente. Cf.( BRANDẢO, 2003).
Tiradentes] comportavam-se austeramente. Eram todas mais ou menos velhas, mas penteadas. calçadas, de colece, a blusil presa por um cinro, a saia preta. Caminhavam como quem vai a um determinado lugar. Paravam como quem espera o bonde. A aproximação de um individuo, punthamtse em guarda, secas, impondo condiçōes. Quando acediam, seguiam disforçadamente. (RIO, 1995, p. 25-26)

Como motivação central, em ambos os contistas, remos a representaçăo de seres arruinados, tomados do mundo empírico como uma coisa entre coisas. Sem o espírito belicoso de Fonseca, Joāo do Rio apreende-os em uma espécie dc contralocal, em um cenário notumo, entrecortado pela iluminaçăo artificial dos automóveis, símbolo inconteste da vida moderna. Para esse espaço marginal, confluem um narrador refinado e uma velha prostituta, D. Joaquina, "uma pobre coitada que faz a na à noite" (ibid., p. 25), duas identidades năo homogêneas de que se serve o autor para metaforizar a falsificação da cidade moderna, tônica, aliás, de seu projeto artístico: sob a engenharia da luz, um individuo pertencente à alta sociedade, um snob movido por esses "sentimentos maus", as sensaçōes, vai captar sua contraparte - a sombra. ${ }^{6}$

Para João do Rio, assim como para Rubem Fonseca, a casa da escrita é a rua. Nas pegadas do autor de "D. Joaquina", "Última noite", "A noiva do som". "A menina amarela", Rubem Fonseca focaliza uma cidade mediada por desesperançados. Entre a personagem e a cidade há uma camada espessa de coisas e seres que é preciso decifrar, uma massa de analfabetos desmemoriados, sem história: "Hei, diz Augusto para um dos jovens [grafiteiros]: "cabaço é com cê-cedilha, vencidos não é com s, e falta um i no grafiteiros" (p.19). Com uma sutileza só encontrada em escritores criativos, o narrador fonsequiano, diante de uma população iletrada, descentrada, vai pondo abaixo as aspiraçōes humanitárias do soltitur almbulando: 
[Augusto e Kelly] chegam ao sebo. Kelly otha, da rua, desconfiada, as estantes no interior das lojas, cheias de livros: 'Existe gente no mundo para ler tantos livros?'. Augusto quer comprar um livro para Kelly, mas ela se recusa a entrar no sebo. Vão até a rua Sāo Josée, dali à rua Graça Aranha, avenida Bejra Mar, Obelisco, Passeio Público." (p.36)

Uma população marginalizada, sem possibilidades de libertaçāo à vista, e uma prostituta avessa à leitura nāo são, certamente, bons depositátios da memória cultural de um povo.

$\mathrm{Na}$ encenação da linguagem, a cidade vai aos poucos arruinando o projeto de Augusto. Se a busca do centro é a metáfora da busca de um Brasil feliz, o leitor já entrevè a dificuldade de o andarilho escrever seu livro.

Passados mais de cem anos desde que Macedo escrevera suas quatrocentos e quatorze belas páginas, um plebeu ignorado pela cultura da letra imprime àquela história uma outra história, desestabilizando, desse modo, o intertexto anterior. Afinal, como já nos dissera Macedo: "Aproveitemos o pouco que temos em uma curtíssima vida de três séculos e meio". (MACEDO, 1942, p. 414)

\section{A cidade-memória}

Saber orientar-se numa cidade nảo significa muito. No entanto perder-se numa cidade, como alguém se perde numa floresta, requer instrução. Nesse caso, o nome das ruas deve soar para aqueles que se perde como o estalar do graveto seco ao ser pisado, e as vielas do centro da cidade devem refletir as horas do dia tão nitidamente quanto um desfiladeiro. (BENIAMIN, 1993, p. 73)

A narração acompanha as andanças de Augusto por ruas que, há cem anos atrás, concentravam a vida artística, intelectual, política e mundana da capital brasileira, como 
7 No momento em que Alencar escreve, a cidade mantinha sua fisjonomia provinciana. colonial. A abertura da Avenida Contral, hoje Rio Branco, se daria no principio do seculo XX (1903-04), sob a administração do prefeito Francisco de Percira Passos.

A esse respeito, ver: Antonio CANDIDO, Radicais de ocasiāo. In: Teresina e etc. Rio de laneiro: Paz e Terra, 1980 e Antonio Arnoni PRADO, Mutilados da belle-ćpoque: notas sobre as reportagens de foào do Rio. In: SCHWARZ, Roberto. Os pobres na liceraturs. brasiloira, Sĩo Paulo: Brasiliense, 1983. a rua do Ouvidor - "ponto de reuniāo dos elegantes e dos ociosos da República" (JÚNIOR, 1894, p. 7), lugar de circulação dos dandys, "alvo do mulherio que passa" (ibid., p. 11), trampolim para encontros amorosos, de onde saíam "os pares de cotillon, dos grandes saraus" (ibid, loc. cit.). Um discreto charme escapava dos estabelecimentos comerciais ali situados, como a loja de Mme. Lambert, onde a mulher "reina, governa e ad ministra" (ibid., p.10), o hotel Ravot, "onde se hospedavam os fazcndeiros ricos da provincia" (ibid., p. 9) e a confeitaria dos Castellōes, ponto de retuniāo de "literatos, jornalistas, poetas, romancistas, músicos, deputados, que comentam os acontecimentos do dia, entre um homérico queijo suíço e latas de doce" (ibid., p. 12).

Não é de estranhar, pois, que nossos melhores escritores tenham explorado cm páginas memoráveis esse lado mais limpo da cidade, muito embora pelas redondezas proliferassem as tascas, e por ali passassem ambulantes, escriturários, prostituras, mendigos, como, aliás, anotou Alencar em certos entrechos de $A$ viuvinha.

Como que antecipando Rubem Fonseca, Joāo do Rio, numa postura de desmascaramento do processo civilizatório, puxava um saldo humano, ${ }^{8}$ a vagar pelos lados obscuros da cidade:

A mendicidade é a exploraçāo mais regular, mais tranqüila desta cidade [...]. Nos pontos de bondes, pelas ruas, guiadas sempre por crianças de frases inexpressivas, vemos tristes criaturas com as māos estendidas [...]. Há a Antonia, a Maria, a Zulmira, a viúva Justina, a D. Abrosina. (RIO, 1952, p. 166)

É porque possuía uma consciência muito nitida de sua história, o cronista carioca anota, à maneira de um etnógrafo, a história das ruas, salvaguardando-as, pela memória, da destruição predatória:

Vede a rua do Ouvidor. É a fanfarronada cm pessoa [...]. Começou por chamar se Desvio do Mar. [... 
[. No tempo em que os seus meihores prédios se alugavam por dez mil réis, era a rua do Gadelha. [...] Um dia resolveu chamar-se do Ouvidor sem que o senado da cámera fosse ouvido. [...]. A rua da Misericórdia, com as suas hospedarias lôbregas [...] é perpetuamente lamentável. Foi a primejra rua do Rio. Dela partimos todos nós, nela passaram os vice-reis malandros, os gananciosos, os escravos nus, os senhores em rede; nela vicejou a imundície. nela desabotoou a fior da influência jesuitica [...]. há (sic) ruas que, pouro honestas no passado, acabaram tomando vergonha. Essa tinha mesmo de mudar de nome. Chamou-se do Açougue Velho, do Inácio Castanheira, do Sucúsarará, do Tomé da Silva, que sei eu? Aré mesmo Canto do Tabaqueiro. Acabou Quitanda do Marisco, mas, como certos individuos que organizam o nome conforme a posiçāo que ocupam, cortou o marisco e ficou só Quitanda. (RIO, 1951, P. 10-16)

Sabedor do ofício de andar pelas ruas do Rio de Janeiro, João do Rio antecipa Rubem Fonseca. Trilhando um caminho entre o real e o estético, e sem os revólveres e os assaltos que tanto marcaram sua escrita, o autor de " $\mathrm{O}$ cobrador" escava, infatigavelmente, a biografia das ruas e dos lugares que se foram: "Agora Augusto está na tua do Ouvidor, indo em direçāo à ráa do Mercado, onde não há mais mercado algum, antes havia um, uma estrutura monumental de ferro pintada de verde, mas foi demolido e deixaram apenas uma torre" (p. 49). E, à maneira do cronista carioca, vai fazendo da rua o chāo đa memória:

Uma mulher que toma um cafezinho é escolhida [por Augusto] porque não tem um dente na frente. [...] "Vocé está ]iv're?". Ela informa o preço e menciona um hotel na rua das Marrecas, que antes se chambara rua das Boas Noitese havia ali a Casa dos Expostos da Santa Casa. mais de cem 
anos acrás. E a rua já se chamou rua do Ladário e se chamou também rua André Rebouças, antes de ser rua das Marrecas, c depois seu nome foi mudado para rua Juan Pablo Duarte, mas o nome nāo pegou c voltou a ser rua das Marrecas. Augusto diz que mora perto e propōe irem para a casa dele. Caminham ambos constrangidos. (p. 21; grifo nosso)

Nessa linha memorialista, e em meio ao processo de reificaçāo de Kelly, Augusto prossegue sua missâo humanitária de conscientização da prostituta. Abandonando meios formais (a leitura de jormais), de resto, inoperantes, apela para a tradição musical do pais:

Antigamente havia botequins espalhados pela cidade, onde vocè sentava e pedia: seu garçom faça o favor de me trazer depressa, uma boa média que nāo scja requentada, um pào bem quente com manteiga à beça - você não conhece a música do Noel?

- Noel? Não é do meu tempo. Desculpe", diz Kelly. (p. 31)

A leitura da cidade seria uma tentativa a mais que possibilitaria a inserção de Kelly em seu caminho de libertação. Mais uma vez, o mundo da memória vem à tona. Trazido poeticamente para o texto literário, o discurso da lembrança é rejeitado. A jovem avessa aos livros e cuja perspectiva de vida é se tornar membro da Associação das Prostitutas ("Mas ai descobri que tem três associaçōes de prostitutas e eu nāo sei para qual delas entrar" (p.30), é talvez uma das realizaçōes literárias mais completas da "consciência coisificada":

La consciencia coisificada se queda forzosamente presa en los dos extremos del empirismo grosero y de la utopia abstracta, análogamente y con la misma falta de perspectivas. Con ello la consciencia se convierte on mero espectador 
pasivo de un movimiento de la cosas según leyes externas, sin poder intervenir de ningún modo en él, o bien se considera a sí misma como un poder que consigue, a su objetiva voluntad, dominar el movimiento de las cosas, en sí sin sintido. (LUKACS, 1975, p. 84)

Com uma percepçào falha e incompleta de sua condiçāo social, Kelly recusa ver na Avenida Rio Branco - icone emblemático do controverso processo de urbanização do Rio de Janeiro, reino do consumo e dos prazeres mundanos - parte da história da cidade. Nảo há em Kelly nenhum gesto latente de dirigir-se para seu presente, nem para seu passado nem para seu futuro:

Augusto e Kelly comern um hambúrger com suco de laranja.

"Eu vou te levar para ver a avenida Rio Branco."

"Eu conheço a avenida ró Branco" [diz Kelly]

"Vou te mostrar os três prédios que nâo foram demolidos. Eu te mostrei a foto da Avenida antigamente?

"Não me interessa essa velharia. Páła com isso." (p. 31; grifos nossos)".

De metáfora em metáfora, e sem querer incorrer no risco de interpretaçôes comparatistas duvidosas, parece-nos que esse perambular angustiante de Augusto à procura de matéria para seu livro - guardadas as devidas contingências históricas e estéticas - aproxima-o da metáfora do poeta-esgrimista baudelairiano, que Benjamin, aprofundando as reflexōes de Gustave Khan. elege como contraçāo preliminar do poeta moderno:

A apreciação mais feliz [sobre a imagem do artista em Baudelairel é do simbolista Khan quando diz que "o trabalho poético parecia ent Baudelaire como um esforco fisico". Encontra-se na ohra deste una prova de afirmaçāo em uma netáfora
O nome americanizado de Kelly seria mais um obstáculo que a impede de compreender suá culura. Ha, sem dúvida, ent Fonseca, uma crítica à invasāo de signos culcurais estrangeiros. No entrecho citado. por exemplo, Augusro e Kelly comem um hamburger, aptopriamse, pois, de hábitos estronhos à cultura brasileira. 
que merece ser analisada mais de perto. Nesta, Baudelaire gostava de apresentar os traços marciais como traços artisticos. (BENJAMIN, 1975, p. 7)

10 JUNIOR, Magalhāes. Antologia dos poetas franceses (do século XV ao século XX). Rio de Janeiro: Gráfica Tupy, 1950. p. 32. A traduço deste poema é de Fonroura Xavier. Ver, abaixo, o original. Le long du vieux faubourg, oil pendent ilux masures

Les persiennes, abri de secrètes luxures,

Quand le soleil frappe à traits redoublés

Sur la ville et les champs, sur les toits et less blès,

Jo vais miexercer à ma fantasque escrime, Flairant de tous les coins les hasards de la rime,

Tróbuchant sur les mots comme sur les pavśs,

Heurtant parfois des vers depuis longtemps révés

(BAIJDEI.AIRE,

Charies. Los Aeurs du ninh Paris: Librairie Géuérale Française,

1964, p. 113.
Em sua complexa formulação alegórica, Benjamin percebe, em Baudelaire, uma relação dialética entre o estético e o heroico, disseminada em toda sua obra poética e adensada neste poema intitulado "Le soleil' ("O sol"):

Quando pelo arrabalde as persianas descidas Velam de madrugada sobre as casas adormidas E mal desperto o sol, com seus raios amigos, Bate já os choupais, os caminhos e os trigos,

Gosto de me entregar aos assaltos da esgrima E acontece, ao cajr a fundo sobre a rima Aos encontrōes num Verbo, aos pulos no valado, Colher um verso em fior há séculos sonhado.,"

O que daria à personagem de Rubem Fonseca o estofo (retardatário) de um esgrimista é que ela tem consciência de que vive um embate com a cidade, lançando-se em uma aventura solitária que exige esforço e dedicação. Un ponto alto deste embate está no diálogo abaixo, no qual a ousadia do palavrão e o humorismo antipoético, tipicamente fonsequianos, aliam-se (sem minimizar o estético) ao mais cru realismo, como forma de acentuar a posição constrangedora de um escritor diante de uma cidade que castra sua voz, que o esmaga e o reprime:
Benevides disse [afirma Augusto] que o senhor [Zé Galinha] é presidente da Uniäo dos Mendigos".

"L vocé, quem é?"

"Estou escrevendo um livro chamado A arte de andar nas ruas do Rio de Janeiro.

"Mostra o livro", diz o sujeito do colar de três voltas.

"Não está pronto"

"Gomo é seu nomo?" 
Aug - Epifânio"

"Que merda de nome é esse?"

"Revista ele", diz. Zè Galinha. (p.45)

Perfila-se, assim, a agonia de um ser asfixiado. É preciso encontrar meios para reagir. Mas, como? Em vários momentos na narraçâo, Augusto procura, à noite, abrigo nas árvores que circundam o Campo de Santana: "Abraça e beija as árvores, o que tem vergonha de fazer à luz do dia na frente dos outros; algumas são tāo grandes que ele não consegue juntar os dedos das mãos atrás delas". (p.27); "passeia por entre os baobás, as figueiras, as jaqueiras ostentando frutos" (p.25). Esse reduto de paz e tranquilidade guarda uma recôndita harmonia com um mundo puro, despoluido, primitivo, natural, "sem verticalidade" (ARGAN, 1995). Ao formular que na cidade moderna "o individuo nāo é mais do que um átimo na massa" (ibid., p. 214), Argan afirma que a cidade vertical, superdimensionada pelo urbanismo desenfreado, desvirtuou a unidade homem-natureza, gerando a impessoalidade e eliminando o ego. "eliminado o valor do ego elimina-se o valor da história de que o ego é protagonista." (ibid., loc.cit.)

É nesse mergulho nas origens primordiais que a personagem-esgrimista busca sua força: "Augusto mostra as árvores para Kelly, diz que elas têm mais de duzentos anos, fala no mestre Valentim, mas ela nào se interessa." (p.36)

O solvitur ambulando está exausto. Em sua luta contra a cidade, há sempre uma pessoa a seu lado, muito sugestivamente chamada de Velho (a inicial maiúscula simboliza o respeito à tradiçāo), a única personagem com quem a interlocução é possível. Sabe-se que nas sociedades ágrafas, o Velho é respeitado porque está deixando para a post eridade o legado da tradiçāo:

Todo mundo conhece a fórmula de Hampate Ba. segundo a tual. תa Africa. um velho que motre é "uma biblioteca que se queina"; porém o 
informante, velho ou nảo, é alguén com quem se discute e que fala menos do passado que daquilo que ele sabe ou persa do passado. Ele nāo é um contemporâneo do acontecimento que relata, mas o etrólogo é contemporâneo da enunciação e do enunciante. A palavra do informante vale tanto para o presente quanto para o passado. (AUGE, 1994, p. 14-15)

$\mathrm{Na}$ memória deste Velho, permanecem os rastros do que se foi. Na citaçāo abaixo, o discurso nostálgico, interrompido por uma espécic de refrảo ("Come o arroz, vai ficar frio"), pode até suscitar o riso. Mas o riso está ai exatamente para amortecer a dor surda do Velho. A prova de que as imagens do presente conflitam com as lembranças do passado está na fusão de duas cenas contrastantes: a visão dos mendigos e o othar fixado em uma janela - fenda que o presente corroeu.

O Velho vai sair com [Augusto e Kelly] porque Augusto prometeu que vão almoçar no Timpanas, na rua Sào José. o o Velho namorou uma moça inesquecível que morava num prédio ao lado do restaurante, construido em mil novecentos e poucos e que ainda tem, intactos, balcões de ferros, timpanos e cimalhas decoradas com estuque. [...] $\bigcirc$ Velho está olhando os prédios. muito compenetrado, encostado ra grade de ferro que cerca o antigo Buraco do Lume, que depois de tapado virou um gramado com poucas arrotes. onde moram alguns mendigos.

"Teu arroz já chegou", diz Augusto.

"Está vendo aquela sacada ali, daqucle sobrado pintado de azul? As três janelas do primeiro andar? Foi naque/a janela à nossa direita que eu a vi, pela primeirit vez, debruçada no balcjo. de cotovelos apoiados numa almofadinha com bordados vermethos.

"Come o arroz, vai ficar frio", diz, Augusto. 
"Ela mancava de uma perna. Isso para mim nāo tinha importância. [...].

"Come o arroz, vai ficar frio". (p. 37-38; grifos nossos)

Nào se trata, de modo algum, de um passadismo idealizado, como se poderia à primeira vista pensar, pois a lembrança não é tão somente uma saudade vazia. Será talvez - e tão só - a manifestação de uma consciência esgarçada. A demoliçāo falsifica ou deforma, é que nos diz, a cada momento, o narrador fonsequiano, ecoando João do Rio (1909, p. 47): "Estávamos na Avenida Beira Mar, sombria, deserta, naquele trecho que foi o Russel". $\mathrm{E}$, ao presenciar in loco a demolição do velho mercado, o cronista avança um argumento moral - a urbanizaçăo do Rio de Janeiro é um processo uniformizador de mentes e culturas:

Acabou de mudar-se ontem a praça do Mercado. [...]. Aquela mudança era, entretanto, maior do que todas, era uma operaçāo de cirurgia urbana. era para modificar inteiramente o Rio de outrota [...]. Que nos resta mais do velho Rio antigo, tăo curioso e tão caracteristico? Uma cidade moderna é como todas as cidades modernas [...]. O Rio. cidade nova - a única talvez no mundo - cheia de tradiçōes, foi dela se despojando com indiferença. De súbito, da noite para o dia, compreender que era preciso tal qual Btıenos Aires, que é o esforço despedaçante de ser Paris, e ruíram casas e estalaram igrejas, e desapareceram ruas [...]. (RIO, 1909, p. 213-215).

O lugar palimpsesto, afirma De Certeau (1994. p. 310), é a celebraçāo de lugares que se foram: "Relatos de lugares são bricolagens, sāo feitos com residuos ou detritos do mundo". Mais uma vez, o narrador, pela voz do Velho, concilia, em dois tempos simultâneos, esse dilaceramento: 
11 Năo pretendemos detalhar as convergéncias e divergéncias de pensamento entre os dois escudiosos. Augé dialoga o rempo todo com De Certeau, comentando suas asserçỏes, citando-o. inclusive. "A distinçīo entre lugares e nāo lugares passa pela oposição do lugar ao espaço. Michel de Certeau propós, das noçues de Iugar e de espaço, uma análise que constitui, aqui, urn anrecedente obripatónio". CF. AUGF., 1994, p. 75.
Durante muito tempo, depois que o Rui [Barbosa] morreu, e até o cinema virasse uma sapatarja, a cadeira dele ficou isolada por um cordào de veludo e havia uma placa dizendo Esta cadeira era ocupada pelo senador Rui Barbosa. Votei nele para presidente duas vezes, mas os brasileiros sempre elegem os presidentes errados (p. 41).

Em Rubem Fonscca predomina o rompimento da solidariedade interna das coisas, cujo exemplo é a convivência absolutamente paradoxal de um cinema, que à noite exibe filmes pornográficos e, de dia, transforma-se em um templo evangélico, gerando a expressāo antinômica cinema-cemplo. Nesta linha, na cidade supermoderna, os sentidos dos lugares identitários, relacionais e históricos podem se apagar:

Se urn lugar pode se definir como identitário, relacional e histórico, um espaço que nảo pode se definir nem como identitário, nem como relacional, nem como histórico definirá um năolugar. A hipótese aqui defendida é a de que a supermodernidade é produtora de não-lugares, isio é, de espaços que não são em sî luggares antropológicos e que, contrariamente à modernidade baudelairian. não integram os lugares antigos: estes, repertonados, classificados e promovidos a "lugares de memórias." ocupam aí um lugar circunscrito e especifico. (AUGÉ, 1994, p. 73)."

Joăo do Rio parecia ler consciência de que habitava, na acepçāo de Augé (1994, p. 53). um lugar antropologico que a urbanização derrubou: "o lugar antropológico [para aqueles que nelo vivem] é histórico na exata proporção em que escapa à história como ciência, [...]. O habitante do lugar antropológico não far. história, vive na história". A partir do momento em que se colocam dois lugares - o lugar sepultado e o lugar que o sepultou, a rasura faz morada: 
Augusto tem um destino naquele dia [...]; ainda que pareça deambular, não anda exatamente ao léu. Pára na na do Teatro e olha para o sobrado onde sua a ró moratia em cima do que agora é uma loja que vende incenso, velas, colares, charutos e outros materiats de macumba, mas que outro dia era uma loja que vendia retalhos de tecidos baratos. (p. 23)

$A$ cidade naao entra sozinha, entra pela porta envolvente da lembrança. Como Joảo do Rio, Rubem Fonseca concebe-a como uma presença de ausencias, nos termos de De Cerreau:

A dispersão dos relatos indica já a do memord́vel. De fato a memótia é o antimuseu: ela não é localizável. Dêla saem clarōes nas lendas [...]. A lembrança é somente um principe encantado de passagem, que desperta, um momento, a BelaAdormecida-no bosque de nossas histórias sem palavras. "Aqui aquierauma padaria"; "ali morava a mere (sic) Dupuis" O que impressiona mais, aqui, é o fato de os lugares vividos serem como presença de ausênciàs. $O$ que se mostra designa aquilo que não é małs: "aq̣ui vocês vêen, aqui havia..,"mas isto nāo se vê mais". (DE CERTEAU, 1994, p. 189; grifos do autor)

A medida que a narraçâo avança, o narrador fonsequiano vai se tornando mais reflexivo e amargurado. Se antes a enunciaçāo era desprovida de ansiedade, agora o conflito entre a personagem e a cidade explode. Os sentidos do centro se apagam de vez. Em uma crise de discernimento, o andarilho busca una saida na morte: Você quer consertar este mundo torto? parece lhe dizer o Vclho de "mente arguta" (p. 17):

Augusto nào sabe o que fazer com Kelly. Diz que vai à loja conversar com o Velho. 
O velho está deitado, no quartinho do fundo da loja. É uma cama tāo estreita que ele só não cai dela porque não dorme nunca.

"Posso falar um pouco com o serhor?"

$O$ Velho sentado na cama faz um gesto para Augusto sentar-se ao seu lado.

"Por que as pessoas querem continuar vivas?

"Você quer saber por que eu quero continuar vivo?, sendo tão velho"?

"Nāo, todas as pessoas."

"Por que você quer continuar vivendo?", pergunta o Velho.

"Eu gosto das árvores. Quero acabar de escrever meu livro. Mas às vezes penso cm me matar. Hoje Kelly me abraçou chorando e tive vontade de morrer".

"Você quer morrer para acabar com o sofrimento dos outros? Nem Cristo conseguiu isso". (p. 48)

Augusto toma consciência de que a carência social e cultural cria uma situaçāo sem volta. Neste domingo cinzento, seu relógio de marca estrangeira continuará soando as horas, os restaurantes do centro estarão fechados, os miseráveis continuarão passando fome, Kelly continuará à sua espera e a cidade continuará exalando seu habitual mau cheiro:

Quando Augusto chega no cais Pharoux, oiha para trás e não vê ninguém.

Seu Casio Melody toca a música de Haydn das três da madrugada, está na hora de escrever seu livro, mas ele nāo quer voltar para casa e encontrar Kelly, Solvitur ambulando. Vai até o cais dos Mineiros, caminha até a estação das barcas, na praça Quinze, ouvindo o mar bater na muralha de pedra.

Espera o dia raiar, em pé na bejra do cais. As águas do mar fedem. A maré sobe e baixa de encontro ao paredão do cais, causando um som que parece 
um suspiro, um gemido. É domingo, o dia surge cinzento; aos domingos, a maioria dos restaurantes do centro não abre; como todo domingo, será um dia ruim para os miseráveis que vivem dos restos de comida jogados fora. (p. 50).

Fusionado, o nome Augusto-Epifânio adquire um valor literário significativo, oposto à tradiçāo patristica católica. Pois, se o nome Augusto remete à vocaçāo do homem justo, altaneiro, e o nome Epifânio é derivado de epifania (Epifânio é aquele que poderia ser chamado de bem-aventurado), concebida como o momento de uniảo com Deus, a visão epifânica do escritor-andarilho, porque enraizada na vida terrena, não comporta nenhuma visāo de felicidade. Rubem Fonseca nảo retoma a experiência de Epifânio como êxtase, como um "fora de si". Pelos intersticios da narraçāo, percebe-se que uma sociedade só é viável quando possui uma forte convivência com a memória, que é uma construçāo humana. Há algo de nostálgico e doloroso nesse perder-se benjaminiano. Em sua errância pela cidade, Augusto-Epifảnio encontra seres miseráveis e culturalmente falhos. O projeto do escritoresgrimista de preencher a página em branco só poderia soçobrar. Gloriosamente. 


\section{Referências}

AUGÉ, Marc. Nào-lugares : introduçāo a uma antropologia da supermodernidade. 5. ed. Trad. Maria Lúcia Pereira. Campinas: Papirus, 1994.

BENJAMIN, Walter. Rua de mảo única, 3. ed. Trad. Rubem Rodrigues Torres Filho. In: Obras escolhidas. São Paulo; Brasiliense, 1993. v. JI. . Charles Baudelaire - um lírico no auge do capitalismo. Trad. José Martins Barbosa c Hemerson Almeida Batista. São Paulo: Brasiliense, 1995.

BRANDĀO, Gilda Vilela. Sem feitio de acabado: a sombra, uma categoria na crônica a na ficçào de Joào do Rio. Tese de doutorado. Ufal, 2003.

DE CERTEAU, Michel. A invenção do cotidiano: artes de fazer. 7. ed. Trad. Ephraim Ferreira Alves. Petrópolis: Vozes, 1994.

FIGUEIREDO, Vera Frollain. Os crimes do texto - Rubem Fonseca e a ficção contemporánea. Belo Horizonte: UFMG, 2003.

FONSECA, Rubem. "A arte de andar nas ruas do Rio de Janeiro". In: Romance negro e outras histórias. Săo Paulo: Scwař, 1992. p.11-50.

IITRIK, Noé. Canónica, regulatoria y rransgresiva. In: GRAMUGLIO et alji. Dominios de la literatura: acerca del Canon Buenos Aires: Losada, 1998. p. $19 \cdot 41$.

JUNIOR, França. Folhetins. 2. ed. (correta e aumentada). Rio de Janeiro: Livraria J. R. Santos, 1894.

LEITE, Miriam Moreira. (Org.). A condiçăo feminina no Rio dé Janeiro - século XIX. São Paulo: I lucutec; Rio de janeiro: INL, 1984 . 
LUKACS, Georg. Consciencia de clase. In: Historia y consciencia de clase. Trad. Manuel Sacristán. Barcelona : Grijalbo, 1975. p. 49-89.

MAURO, Frédéric. Le Brésil à la fin du XVIlème siècle. Paris : Sedes, 1977.

RIO, João do. Cinematógrafo (crônicas cariocas). Porto: Chadron, 1909. $\triangle$ alma encantadora das ruas. Rio de Janeiro: Organização Simōes, 1952. A mulher e os espelhos. Rio de Janejro: SEEC, 1995. 